\title{
Estimation of Liveweight from Chest Girth and Wither Height Measurements in West African Dwarf Goats
}

\author{
I. J. James, O. A. Osinowo and T. O. Amoo \\ Department of Animal Breeding and Genetics, University of Agriculture, Abeokuta, Nigeria
}

\begin{abstract}
Linear and geometric regression equations were used to estimate liveweight of two hundred and eighty six semi-intensively managed West African Dwarf (WAD) goats from Chest girth (CG) and Wither height (WH) measurements. $C G$ accounted for 52 and $58 \%$ variation in the liveweight of goats using linear and geometric equations respectively, thus showing a curvilinear relationship. WH accounted for $31 \%$ variation in liveweight of goats using both equations. CG measurement was found to be more reliable for estimating liveweight of WAD goats than WH measurement. Using linear regression equation, $C G$ and WH estimated the liveweight of females better than males with average increases of $57 \%$ and $25 \% R^{\prime}$ values respectively. Using geometric regression equation. $C G$ and WH also estimated the liveweight of females better than males with uverage increases of $55 \%$ and $22 \% R^{2}$ values respectively. In essence, $C G$ and $W H$ measurements estimated the liveweight of does better than bucks using both regression equations. Generally, CG and WH better estimated the liveweight of goats that are greater or equal to 3 years old than goats that are greater than I year but less than 3 years old and goats that are less or equal to 1 year old using both regression equations. Even though, each of the geometric or linear regression equations may be used to estimate liveweight of WAD goats with a high degree of reliability in a specific class of animals, it would be simpler and less cumbersome to use the regression equation obtained from pooled data to estimate liveweight in all animals.
\end{abstract}

Key words: Linear, geometric, regression equations, chest girth, wither height

\section{Introduction}

Goats have successfully served mankind with meat, milk, hair, leather and other products including manure, even though they are frequently objects of neglect and prejudice. The liveweight measurement in goats is a useful tool in health and feed management. It also provides basis for reproduction, performance monitoring and marketing of its products. However, this trait is rarely measured in rural areas where majority of these animals are kept (Mayaka et al., 1995) due to lack of reasonable accurate record and weighing scales. The main method of liveweight determination is by regression of body weight on linear body measurements (Poivey et al., 1980; Buldgen et al., 1984).

Several research findings have shown that linear body measurements are closely related to liveweight change of animals (Brody and Davies, 1937; Bhachila et al., 1979; Antobam, 1983 and Berny, 1997). Nigeria has a total of 34 million goats of which West African Dwarf (WAD) ranks second numerically (RIM, 1991; Osinowo, 1992; Lamorde, 1997) and majority of which are kept in the rural areas. They are particularly important 
animals in the subsistence agriculture on account of its unique ability to adapt itself to harsh environmental conditions. This has becn ascribed to the definite physiological characteristics and high economic viability, which included feed intake digestive capacity, fertility, low initial cost and almost complete absence of prejudices or taboo against it or its product (Steele, 1996). Therefore, the importance of goats in the livelihood of rural African people cannot be over emphasized. Nevertheless, since WAD goats are of much importance and they are well adapted to the Southwestern part of the country, it is worthwhile using them for this study, since elsewhere (Brody and Davies, 1937 and Mayaka et al., 1995) heart girth is generally accepted as a single most reliable variable for growth in goats. Therefore, the objectives of this study were to derive predictive equations for estimating liveweight of West African Dwarf sheep using chest girth and wither height as regressors and to assess their accuracies.

\section{Materials and Methods}

Animal management and experimental procedure

The study was conducted in thirty-two villages in Abeokuta North and South, Yewa North and South and Odeda Local Government Areas of Ogun State; all located in the Southwestern Nigeria. The region lies within the humid zone of the country. It has an average annual rainfall of $1458 \mathrm{~mm}$. The annual temperature ranges between $28^{\prime \prime} \mathrm{C}-32^{\circ} \mathrm{C}$. Two hundred and eight six West African Dwarf goats were used for the study comprising 148 males and 138 females. The liveweight of the animals ranges between 4.0 $24.2 \mathrm{~kg}$. The prominent management system found in the study area was the semi-intensive system. The liveweight of animals was taken with the use of a hanging scale with $0.1 \mathrm{~kg}$ graduation. The chest girth and the wither height were measured by means of a flexible canvas tape rule.

\section{Data analysis}

The liveweight of the animals was regressed on the measured chest girth and wither height with respect to their sex, age class and for all animal irrespective of sex and age class. The regression analyses were carried out by imputation of the regression equations into linear and non-linear regression modules of SYSTAT (1992) for the generation of parameters needed for evaluating their fitness on the data. The module was set at 100 iterations while simplex method was adopted which calculate the loss function at different points until the minimum is reached before generating the parameters. A linear and five nonlinear regression equations were fitted on the data generated as presented in Table 1. However, only the linear and the geometric (non-linear) regression equations consistently generated parameters and showed convergence with higher coefficient of determination $\left(\mathrm{R}^{2}\right)$ values, hence they were subsequently adopted.

The differences between estimated and observed liveweights were calculated and expressed as percentage of observed liveweight and called "percentage difference."

\section{Results and Discussion}

Ranges and means of liveweight, chest girth (CG) and wither height (WH) of West African Dwarf (WAD) goats are presented in Table 2 and the results of the use of linear and geometric regression equations for estimating liveweight of WAD goats from $\mathrm{CG}$ and $\mathrm{WH}$ measurements are shown in Table 3 .

The liveweight, CG, and WH means for male and female goats sampled were $9.3 \mathrm{~kg}$ and $15.2 \mathrm{~kg}, 48.3 \mathrm{~cm}, 58.4 \mathrm{~cm}$ and $40.9 \mathrm{~cm}$ and $42.3 \mathrm{~cm}$ respectively (Table 2 ). The tr:nd could be explained by the fact that the prasant goat owners prefer to sell or slaughter $r: 1$ : :zoats while keeping female goats for multip $c$ : tion of their stock. It was also observed tha' $t$ : liveweight, 
Table 1. Linear and non-linear regression equations used for estimating liveweight of West African Dwarf goats.

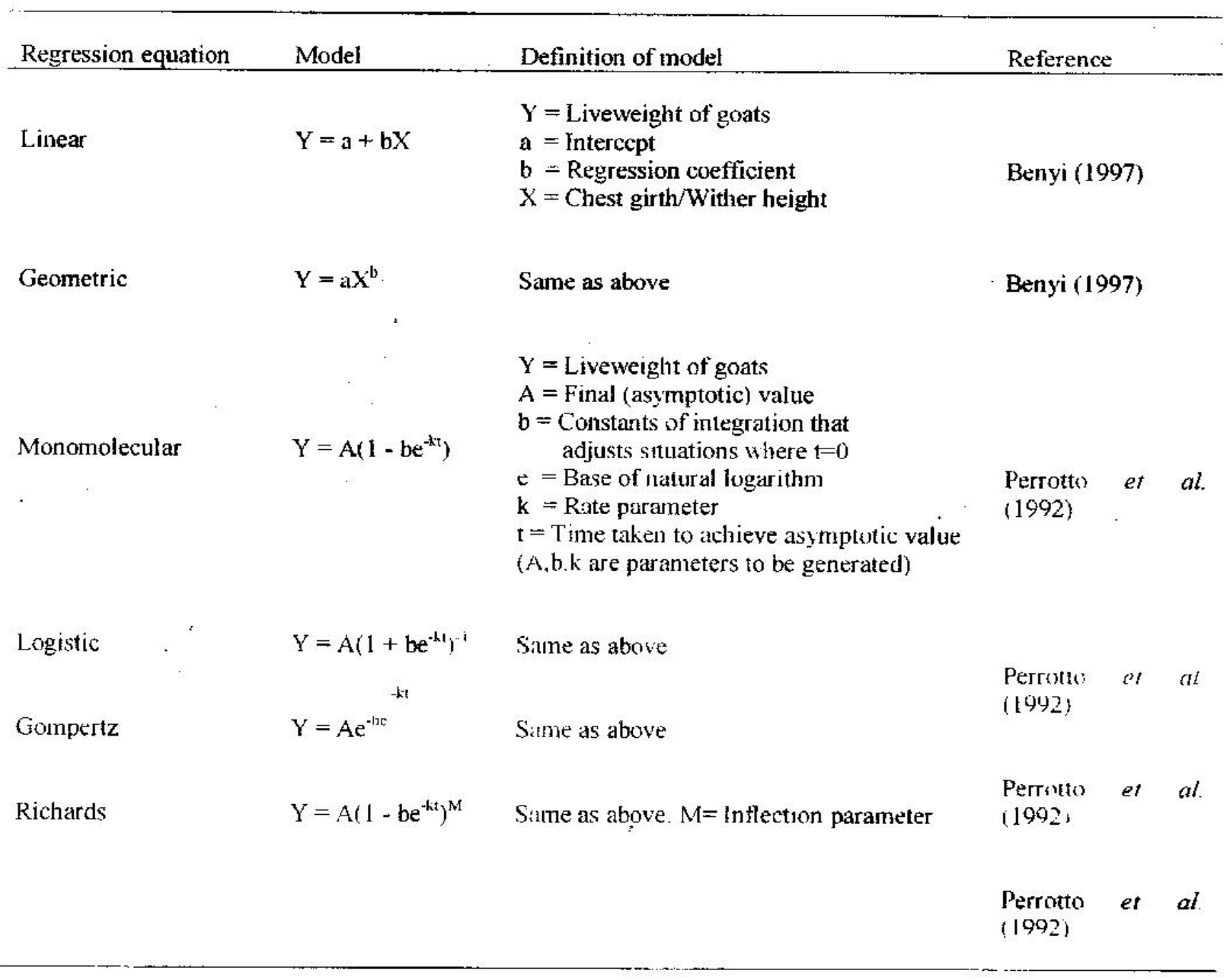

Table 2. Ranges and means in liveweight, chest girth and wither height of West African Dwarf goats

\begin{tabular}{|c|c|c|c|c|c|c|c|}
\hline \multirow[b]{2}{*}{ Group } & \multirow[b]{2}{*}{ No. } & \multicolumn{2}{|c|}{ Liveweight, $\mathrm{kg}$} & \multicolumn{2}{|c|}{ Chest girth, cm } & \multicolumn{2}{|c|}{ Wither height, cm } \\
\hline & & Ranges & Means & Ranges & Means & Ranges & Means \\
\hline \multicolumn{8}{|l|}{ Sex } \\
\hline Male & 148 & $4.0-21.2$ & 9.3 & $35.0-70.0$ & 48.3 & $27.0-55.0$ & 40.9 \\
\hline Fenale & 138 & $4.8-24.2$ & 15.2 & $36.0-73.0$ & 58.4 & $31.0-53.0$ & 42.3 \\
\hline \multicolumn{8}{|l|}{ Age } \\
\hline$\leqslant 1$ Year & 98 & $4.0-15.0$ & 6.4 & $35.0-64.0$ & 43.3 & $27.0-52.0$ & 36.8 \\
\hline$>1<3$ Year & 181 & $5.3-24.2$ & 15.0 & $43.0-73.0$ & 58.0 & $31.0-55.0$ & 44.0 \\
\hline$\geqslant 3$ Year & 7 & $19.0-22.0$ & 21.2 & $65.0-72.0$ & 67.9 & $41.0-49.0$ & 44.0 \\
\hline Pooled data & 286 & $4.0-24.2$ & 12.2 & $35.0-73.0$ & 53.2 & $27.0-55.0$ & 41.6 \\
\hline
\end{tabular}


$\mathrm{CG}$ and WH measurements of WAD goats increased correspondingly with increase in age. This observation is expected since increase in body size and weight of animals arising from laying down of body tissues and growth of skeletal structures are directly related to age. Generally, the liveweight, $C G$ and $W H$ measurements in WAD goats (Table 2) irrespective of sex and age are within the range reported by Steele (1996) and Amoo (2005), although, value for the liveweight was lower. This could be attributed to the younger males sampled in this study.

The relationship between liveweight and $\mathrm{CG}$ was better described by geometric regression equation (Table 3), which yielded on average, a $1 \%$ higher coefficient of determination $\left(R^{2}\right)$ value than linear regression equation. $\mathrm{CG}$ accounted for 78 and $79 \%$ variation in liveweight of WAD goats using linear and geometric regression equations respectively. This observation corroborates earlier findings that the relationship between liveweight and chest girth in cattle, sheep and goats is curvilinear (geometric) (Kpesese, 1986; Pander et al., 1989) but is at variance with the observation of Mullick (1950) who reported a linear relationship.

The relationship between liveweight and WH was better described by linear regression equation than geometric regression equation with $R^{2}$ values of $37 \%$ and $35 \%$ respectively. This suggests that $\mathrm{CG}$ reasonably reflect entire growth of WAD goats than WH and could reliably predict the liveweight of goats better than WH. Using linear regression equation, CG accounted for 70 and $72 \%$ variation in the liveweight of male and female goats respectively with an average increase of $2 \%$ in $R^{2}$ values. Using geometric regression equation, chest girth accounted for 71 and $73 \%$ variation in the liveweight of male and female WAD goats respectively and WH accounted for 43 and $46 \%$ variation in the liveweight of male and female WAD goats respectively. However, WH accounted for up to 43 and $48 \%$ variation in liveweight of the male and female goats respectively with an average increase of $5 \%$ in $\mathrm{R}^{2}$ values.

In essence, CG and WH measurements estimated the liveweight of does better than bucks using both regression equations. This observation contradicts the findings of Dlamini (1988) in indigenous Swazi goats that chest girth is a more reliable predictor of liveweight in males than in females and the observation of Benyi (1997) who reported that liveweight could be estimated from chest girth with the same degree of reliability in male and female sheep. The reason could be that the male goats used in this study were much younger with lighter body weights than the female goats and are still be within their growing phase (Table 2).

Generally, Table 3 shows that both CG and WH better predicted the liveweight of goats that are greater or equal to 3 years old than goats that are less than 3 years old using both linear and geometric regression equations. The observation is expected because the range of liveweight of the animals in this group is smaller in values than in other groups (Table 2) thus reducing the level of variability in liveweight of the animals and increasing the accuracy of predicting the liveweight of goats sampled. Table 4 shows ranges and mean percentage differences (PD) of liveweight estimates by various linear and geometric regression equations in WAD goats. Using $C G$, the means in PD of liveweights estimated by geometric regression equation was much smaller than those of the corresponding estimates by the linear regression equation. This agrees with the observation of Antobam (1983) and Benyi (1997) that geometric regression 
Table 3 Linear and geometric negrowion eqpations for estimsting livewight of West African Dwar foats from chest girth and wither haight measurements and their $R^{2}$ values.

\begin{tabular}{|c|c|c|c|c|c|c|c|c|c|}
\hline \multirow{3}{*}{ Group } & \multirow{3}{*}{ No. } & \multicolumn{8}{|c|}{ Regression equations } \\
\hline & & \multicolumn{4}{|c|}{ Linear. } & \multicolumn{4}{|c|}{ Geometric } \\
\hline & & Ohest gith & $\mathbf{R}^{2}$ & Wither beight & $\mathbf{R}^{2}$ & Chest girth & $\mathbf{R}^{2}$ & Wither height & $\mathbf{R}^{2}$ \\
\hline $\begin{array}{c}\text { SEX } \\
\text { Male } \\
\text { Fernale }\end{array}$ & $\begin{array}{l}148 \\
138\end{array}$ & $\begin{array}{l}Y=-13.15+0.47 X \\
Y=-14.94+0.51 X\end{array}$ & $\begin{array}{l}0.70^{\infty \cdots} \\
0.72^{x \cdots}\end{array}$ & $\begin{array}{l}Y=-7.29+0.41 X \\
Y=-22.58+0.89 X\end{array}$ & $\begin{array}{l}0.43^{-* *} \\
0.48^{+* * *}\end{array}$ & $\begin{array}{l}Y=0.001 X^{2.38} \\
Y=0.002 X^{21-1}\end{array}$ & $0.71^{* * *}$ & $\begin{array}{l}Y=0.015^{1.74} \\
Y=0.002 X^{2.35}\end{array}$ & $\begin{array}{l}0.43^{\circ} \\
0.46^{\circ}\end{array}$ \\
\hline $\begin{array}{c}\text { AGE } \\
\leq 1 \text { Year } \\
>1<3 \text { Year } \\
\geq 3 \text { Year }\end{array}$ & $\begin{array}{c}98 \\
181 \\
7\end{array}$ & $\begin{array}{l}Y=-2.12+0.20 \mathrm{X} \\
Y=-14.12+0.50 \mathrm{X} \\
Y=40.15-0.28 \mathrm{X}\end{array}$ & $\begin{array}{c}0.33^{*} \\
0.62^{\cdots} \\
0.57^{*}\end{array}$ & $\begin{array}{l}Y=0.56+0.16 \mathrm{X} \\
Y=-3.13+0.41 \mathrm{X} \\
Y=31.76-0.24 \mathrm{X}\end{array}$ & $\begin{array}{l}0.23 \\
0.11 \\
0.47\end{array}$ & 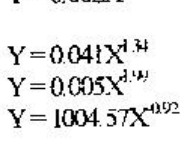 & $\begin{array}{l}0.34^{\circ} \\
0.64 \\
0.64\end{array}$ & $\begin{array}{l}Y=0.250 X^{1911} \\
Y=0.19 X^{1.15} \\
Y=1.51 .93 X^{-132}\end{array}$ & $\begin{array}{l}0.24 \\
0.11 \\
0.56^{*}\end{array}$ \\
\hline Pooled data & 286 & $Y=-15.35+0.52 X$ & $0.78^{-* m}$ & $Y=-14.31+0,64 X$ & $0.37^{*}$ & $Y=0,001 X^{2 x}$ & $0.77^{* * *}$ & $Y=0.007 X^{(2)}$ & $0.35^{*}$ \\
\hline
\end{tabular}

Pe $0.05, " \mathrm{P}-0 \mathrm{OL}$ and "P:0.001

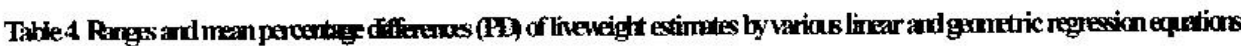
in West Aricion Dwaf gais.

\begin{tabular}{|c|c|c|c|c|c|c|c|c|c|c|c|c|}
\hline \multirow{4}{*}{ Grep } & \multicolumn{6}{|c|}{ Linerar } & \multicolumn{6}{|c|}{ Geumitric } \\
\hline & \multicolumn{3}{|c|}{ Gest girth } & \multicolumn{3}{|c|}{ Wither hingt } & \multicolumn{3}{|c|}{ Ches ginth } & \multicolumn{3}{|c|}{ Witherbeight } \\
\hline & \multicolumn{2}{|c|}{ Ams } & \multirow[b]{2}{*}{ Mans } & \multicolumn{2}{|c|}{ Rapgas } & \multirow[b]{2}{*}{ Mars } & \multicolumn{2}{|c|}{ R.1Es } & \multirow[b]{2}{*}{ Mears } & \multicolumn{2}{|c|}{ Pugs } & \multirow[b]{2}{*}{ Mars } \\
\hline & $\underline{M}$ & $\operatorname{Mec}$ & & Min & Mn & & Mn & $\mathrm{Mnx}$ & & Mn & Mex & \\
\hline $5 x$ & & & & & & & & & & & & \\
\hline Mate & 688 & -285 & $69 \pm 01^{11}$ & 80 & -281 & $47=03^{n}$ & 132 & -29.7 & $-153 \pm 0.5^{\prime \prime}$ & 54.7 & 07 & $37.1 \pm 0.3$ \\
\hline Femile & -200 & -33 & $20 \pm 0.3^{b}$ & -7.5 & 5.6 & $06 \pm 01^{h}$ & -20.9 & -20.2 & $-24.0 \pm 07$ & 19.4 & -85 & $-17.5 \pm 0.7$ \\
\hline Agedas & & & & & & & & & & & & \\
\hline ?1Year & 69.0 & -569 & $43 \pm 03^{\circ}$ & 17.8 & -2639 & $11.9 \pm 0.1^{*}$ & 90 & -465 & & $\begin{array}{l}0.50 \\
836\end{array}$ & $\begin{array}{l}-326 \\
-162\end{array}$ & $\begin{aligned}-27 \pm 06 \\
16 \pm 05\end{aligned}$ \\
\hline $\begin{array}{l}>1 \text { < Y Yea } \\
73 \text { Yea }\end{array}$ & -1825 & -87.1 & $-1041 \pm 04$ & 67.7 & -17.6 & $-09 \pm 03$ & 87 & -320 & $\begin{array}{r}-219 \pm 05 \\
2.1 \pm 0.3\end{array}$ & $\begin{array}{l}856 \\
147\end{array}$ & $\begin{array}{l}-102 \\
-237\end{array}$ & $\begin{array}{c}1.6 \pm 0.5 \\
123 \pm 01^{\prime \prime}\end{array}$ \\
\hline ? 3 Year & 112 & 187 & $9.4 \pm 0.2^{1}$ & 10.4 & 190 & $82 \pm 02^{\prime}$ & 4.3 & 107 & $2.1 \pm 0.5$ & 147 & 20.8 & $123 \pm 01$ \\
\hline Poodeddta & 128 & -123 & 26 & -58 & -132 & 3.0 & 34 & -133 & -14.5 & 1221 & 390 & 7.4 \\
\hline
\end{tabular}

equation estimate liveweight with higher degree of reliability than linear regression equation. However, using WH, the reverse was observed. The results shown in Tables 2,3 and 4 suggest that though each of the geometric or linear regression equations may be used to estimate liveweight with a high degree of reliability in a specific class of animals, it would be simpler and less cumbersome to use the regression equation obtained from pooled data to estimate liveweight in all animals as cited by Benyi (1997).

\section{Conclusion}

The relationship between liveweight and chest girth was better described by geometric regression equation (curvilinear).

The relationship between liveweight and wither height was described with the same degree of reliability by both regression equations.

Chest girth better estimated liveweight of WAD goats than wither height using both linear and geometric regression equations.

Chest girth and wither height estimated the liveweight of does better than the 
bucks using both linear and geometric regression equations.

Generally, chest girth and wither height better estimated liveweight of goats that are greater or equal to 3 years old than goats that are less than 3 years old using both regression equations.

Even though, each of the geometric or linear regression equations may be used to estimate liveweight with a high degree of reliability in a specific class of animals, it would be simpler and less cumbersome to use the regression equation obtained from pooled data to estimate liveweight in all animals.

\section{References}

Amoo, T.O. 2005. Estimation of liveweight and age of West African Dwari goats from chest girth and wither height measurements. B. Agric. Project. Dept. of Animal Breeding and Cenetics, University of Agriculture Abeokuta. Nigeria $30 \mathrm{p}$.

Antobam, K. 1983. Estimation of weighs of sheep from body measurements. B.Sc. Dissertation, Department of Animal Science, University of Ghana, Legon, Ghana

Benyi, K. 1997. Estimation of liveweight from chest girth in pure and crossbred West African Dwarf goats. Trop. Anim. Hlth. Prod., 29: 124-128.

Bhachila, S. K., Bhat. P. N. and R. C. Garg. 1979. Prediction of body weight from body measurement in sheep. Ind. J. Anim. Sci. $49,775-777$.
Brody, S., and H. P. Davies 1937. Growth and development with special reference to domestic animals. Relation between live weight and chest girth in Dairy cattle of Unknown age. University of Mossorri Agricultural Expcriment Station Bulletin 262.

Buldgen, A. Compere, R. and A, Riboux, 1984. Recherche d' une formule barymetrique adaptee aux bovines du typedjakore des elevages villageois du Senegal oriental. Tropicultura, 2: 86-90. Cited by Mayaka, T.B., Tchoumboue. J., Manjeli Y. and Teguia A. In: Estimation of live body weight in West African Dwarf goats from hear girth measurement. Trop. Anim. Hlth. Prod. 28: 126-128.

Dlamini, G. M. 1988. The physical characteristics of the Swazi indigenous goat. B.Sc. Dissertation, Animal Production and Health Department, University of Swaziland, Luyengo.

Kpesese, K. 1986. Estimation of body weight. from linear body measurements in cattle. BSc. Dissertation, Department of Animal Science, University of Ghana, Legon.

Lamorde, A.G. 1997. Research priorities for sustainable women empowerment and development. A paper presented at the National conference on research as backbone for sustainable development held at Abuja, Nigeria on $11^{\text {th }}-15^{\text {th }}$ August, 1997. [cited by Abubakar, M.M. 1998. In: Osinowo, O.A. (Ed.). The commemorative book: 25 years of the Nig. Soc. Anim. Prod. 1973 - 1998. 
Mayaka, T.B., Tchoumboue, J., Manjela, Y. and A. Teguia, 1995. Estimation of live body weight in West African Dwarf goats from hearth girth measurement. Trop. Anim. Hlth. Prod., 28: 126-128.

Mullick, D. N. 1950. The estimation of weights of cattle and buffalo from heart girth measurements. Ind. J. Dairy Sci., 3: 52 -58 .

Osinowo, O.A. 1992. Small ruminant statistics, Nigeria. Mimeograph p. 1 - 5.

Pander, B. L., Kanausia, A. S. and A. S. Yadav, 1989. Growth performance and prediction of body weight from body measurements in Beetal and Black Bengal kids and their crosses maintained under feedlot conditions. Ind. J. Anim. Prod. And Mgt. , 5: $162-$ 166.

Perrotto, D., Cue, R.I. and A.J. Lee, 1992. Comparison of non-linear functions for describing the growth curve of three genotypes of dairy cattle. Can. J. Anim. Sci. $72: 773-782$.
Poivey, J.P., Landais, E and J. L. Seitz, 1980. Utilization de la barymetrie chez les races taurines locales de Cote d' voire. Revue d' Elevage et de Medecine Veternaire des pays Tropicaux, 33:311-317. Cited by Mayaka, T.B., Tchoumboue. J., Manjeli Y. and Teguia A. In: Estimation of live body weight in West African Dwarf goats from hear girth measurement. Trop. Anim. Hlth. Prod. 28: $126-128$.

RIM, 1991. Resources Inventory Management Ltd. Nigerian National Livestock Survey. Federal Department of Livestock and Pest Control Services, Abuja. 287p.

Steele, M. 1996. The tropical Agriculturist. Goats. Macmillan Publishers Limited, $1^{\text {st }}$ edition, London and Basingstoke. Pp: 79-81.

SYSTAT, 1992. Systat Computer Package, version 5.02. Systat, Inc. 1800 Sherman Ave., Evanston, IL USA, 6021, 708.864.5670.

(Received 2nd June 2006; Accepted 22nd Nov. 2006). 